\title{
Nova1 mediates resistance of rat pheochromocytoma cells to hypoxia-induced apoptosis via the Bax/Bcl-2/caspase-3 pathway
}

\author{
HUALING LI ${ }^{1-5^{*}}$, BEI LV $^{1 *}$, LING KONG $^{1 *}$, JING XIA $^{1}$, MING ZHU $^{1}$, LIJUAN HU $^{1}$, DANYANG ZHEN ${ }^{1}$, \\ YIFAN WU ${ }^{1}$, XIAOQIN JIA ${ }^{1}$, SUJUAN ZHU ${ }^{6}$ and HENGMI CUI ${ }^{2,4,5,7}$ \\ ${ }^{1}$ Department of Biochemistry, Medical College of Yangzhou University; ${ }^{2}$ Jiangsu Key Laboratory of \\ Integrated Traditional Chinese and Western Medicine for Prevention and Treatment of Senile Diseases, Yangzhou, \\ Jiangsu 225001; ${ }^{3}$ Jiangsu Key Laboratory of Zoonosis; ${ }^{4}$ Jiangsu Co-innovation Center for Prevention and Control of \\ Important Animal Infectious Diseases and Zoonoses; ${ }^{5}$ Institute of Epigenetics and Epigenomics, Yangzhou University; \\ ${ }^{6}$ Department of Biochemistry, Biosciences and Biotechnology College of Yangzhou University; ${ }^{7}$ Jiangsu Key Laboratory of \\ Experimental and Translational Non-coding RNA Research, Yangzhou, Jiangsu 225009, P.R. China
}

Received February 26, 2017; Accepted July 26, 2017

DOI: $10.3892 / \mathrm{ijmm} .2017 .3089$

\begin{abstract}
Neuro-oncological ventral antigen 1 (Nova1) is a well known brain-specific splicing factor. Several studies have identified Noval as a regulatory protein at the top of a hierarchical network. However, the function of Noval during hypoxia remains poorly understood. This study aimed to investigate the protective effect of Noval against cell hypoxia and to further explore the $\mathrm{Bax} / \mathrm{Bcl}-2 /$ caspase- 3 pathway as a potential mechanism. During hypoxia, the survival rate of pheochromocytoma PC12 cells was gradually decreased and the apoptosis rate was gradually increased, peaking at $48 \mathrm{~h}$ of hypoxia. At $48 \mathrm{~h}$ after transfection of PC12 cells with pCMV-Myc-Noval, the expression of Noval was significantly increased, with wide distribution in the cytoplasm and nucleus. Moreover, the survival rate was significantly increased and the apoptosis rate was significantly decreased. Additionally, the
\end{abstract}

Correspondence to: Professor Sujuan Zhu, Department of Biochemistry, Biosciences and Biotechnology College of Yangzhou University, 88 South University Ave, Yangzhou, Jiangsu 225009, P.R. China

E-mail: hlli@yzu.edu.cn

Professor Hengmi Cui, Institute of Epigenetics and Epigenomics, Yangzhou University, 88 South University Ave, Yangzhou, Jiangsu 225009, P.R. China

E-mail: hmcui@yzu.edu.cn

*Contributed equally

Abbreviations: Nova1, neuro-oncological ventral antigen 1; POMA, paraneoplastic opsoclonus myoclonus ataxia; Bax, Bcl-2 associated gene X; Bcl-2, B cell lymphoma gene-2; caspase-3, cysteinyl aspartic acid specific protease-3; MTT, methyl thiazolyl tetrazolium

Key words: neuro-oncological ventral antigen 1, resistance, hypoxia, apoptosis, pathway
mRNA and protein expression levels of Bax and caspase-3 were significantly increased in the pCMV-Myc group and significantly decreased in the pCMV-Myc-Noval group, whereas that of Bcl-2 was significantly decreased in the pCMV-Myc group and significantly increased in the pCMV-Myc-Noval group. This study indicated that Noval could be linked to resistance to the hypoxia-induced apoptosis of PC12 cells via the Bax/Bcl-2/caspase-3 pathway, and this finding may be of significance for exploring novel mechanisms of hypoxia and the treatment of hypoxia-associated diseases.

\section{Introduction}

Hypoxia is a common pathological process involving abnormal changes in the morphological structure, function and metabolism of tissue due to the lack of oxygen or clinically, to the barrier of oxygen use (1-3). Hypoxia of major organs, such as the brain and heart (4-7), often results in the death of the organism. The combination of the extent, speed, and duration of hypoxia and the organism's metabolic state determine the influence of hypoxia on the organism. Acute severe hypoxia often causes organ compensatory insufficiency, metabolic disorders, irreversible damage and even death (8-10), and chronic mild hypoxia often causes slight compensatory reactions (11-13).

Brain hypoxia often causes severe changes to the internal and external environments of cells, often leading to necrosis or apoptosis and also often activating self-repair mechanisms in response to hypoxic injury $(14,15)$. Recently, although neuronal apoptosis has been well documented at the molecular level, the mechanism remains unknown and the chaos of apoptosis may be closely associated with the genesis and development of multiple nervous system diseases, such as stroke $(16,17)$, cerebral injury $(18,19)$, neurologic tumors and neurodegenerative recession diseases (20-23).

Neuro-oncological ventral antigen (Nova) is one of the first validated mammalian neuron-specific splicing factors, and has been identified as an antigen of paraneoplastic opsoclonus 
myoclonus ataxia (POMA) $(24,25)$. Members of the Nova superfamily, including Nova1 and Nova2, are a type of RNA binding protein that is expressed only in the central nervous system and that can bind the YCAY motif of pre-mRNA of target genes both in vivo and in vitro via its $\mathrm{KH}$ domain, thereby regulating alternative splicing $(26,27)$. Based on the differences in the target binding positions, Nova has a dual function as a splicing regulating factor, both promoting and inhibiting splicing. Nova can recruit other splicing factors when bound to the YCAY motif of pre-mRNA to promote the assembly of the spliceosome, or it can indirectly enhance the assembly of the spliceosome at weak splicing sites (28). In addition, due to steric hindrance, Nova can also inhibit the assembly of the spliceosome (25). Within the Nova superfamilly, Nova1 was initially speculated to regulate alternative splicing due to its KH domain, similar to hnRNP K and MER1. Nova1 is highly evolutionarily conserved and its amino acid homology among human, rat and mouse is $99 \%$, indicating its significant function in organismal biology (29). As demonstrated by several studies, Noval can regulate the alternative splicing of neuronal transcripts, a process that is closely associated with all types of brain physiology and biochemistry, as well as complex nerve systems and elaborate regulatory processes (30). We also showed that Noval may mediate neuronal responsiveness after ischemia-reperfusion insults in the rat brain (29). Therefore, to ascertain whether Noval is involved in hypoxia injury and has a protective effect on neural cells after hypoxia injury, the eukaryotic expression vector pCMV-Myc-Noval was constructed. The results showed that Noval may protect against hypoxia-induced apoptosis in $\mathrm{PC} 12$ cells via Bax/Bcl-2/caspase-3 pathway. As expected, after overexpression of Nova1 protein in PC12 cells subjected to $48 \mathrm{~h}$ hypoxia, the rate of apoptosis was significantly decreased, the mRNA and protein expression levels of Bax and caspase- 3 were significantly decreased, and the expression of Bcl-2 was significantly increased, indicating that Noval protects against the hypoxia-induced apoptosis of PC12 cells via the Bax/Bcl-2/caspase-3 pathway.

\section{Materials and methods}

Construction of eukaryotic expression vector $p C M V-M y c$ Noval. Primers based on the full-length cDNA sequence of Noval (NM_002515.2) were designed according to GeneBank data (http://www.ncbi.nlm.nih.gov/genbank) and chemically synthesized by Invitrogen (Carlsbad, CA, USA) as follows: pU, 5'-TACGTCGACTATGATGGCGGCAGCTCCC-3' (the SalI restriction site is underlined), and $\mathrm{pD}, 5^{\prime}$-TCCCTCGAGTC AACCCACTTTCTGAGG-3' (the XhoI restriction site is underlined). Subsequently, a Noval cDNA fragment (1,503 bp) with SalI and XhoI restriction endonuclease sites was amplified from pCR4-TOPO-Noval by polymerase chain reaction (PCR) using the above-designed primers and then subcloned into the eukaryotic expression vector $\mathrm{pCMV-Myc}$ followed by direct sequencing.

Culturing of PC12 cells and transfection. $\mathrm{PC1} 2$ cells purchased from the American Type Culture Collection (ATCC; Manassas, VA, USA) (CRL-1721 ${ }^{\mathrm{TM}}$ ) were thawed from storage in liquid nitrogen using Dulbecco's modified Eagle's medium (DMEM) with $100 \mathrm{ml} / 1$ horse serum and $50 \mathrm{ml} / 1$ fetal bovine serum. The cells were then cultured to the logarithmic growth phase in a $\mathrm{CO}_{2}$-incubator with $5 \% \mathrm{CO}_{2}$ at $37^{\circ} \mathrm{C}$. After digestion with $0.25 \%$ Trypsin, the cell solution was diluted and incubated in a 6 -well plate $\left(3 \times 10^{5}\right.$ cells/well) followed by culturing in a $\mathrm{CO}_{2}$-incubator with $5 \% \mathrm{CO}_{2}$ at $37^{\circ} \mathrm{C}$. When the cells reached $\sim 80-90 \%$ confluence, a total of $2 \mu \mathrm{g}$ of pCMV-Myc and pCMV-Myc-Noval plasmids was transfected into PC12 cells using Lipofectamine 2000 (Invitrogen) according to the manufacturer's instructions. First, $2 \mu \mathrm{g}$ of plasmids, including pCMV-Myc and pCMV-Myc-Noval, was mixed with $50 \mu 1$ of Opti-MEM serum-free medium (solution A; Gibco, Grand Island, NY, USA). Then, $5 \mu \mathrm{l}$ of Lipofectamine 2000 was mixed with $50 \mu 1$ of Opti-MEM serum-free medium (solution B) and incubated at room temperature (RT) for $5 \mathrm{~min}$. Finally, solution A and solution B were mixed and incubated at RT for $20 \mathrm{~min}$, after which they were added to 6-well plates for transfection. At 24, 48, 72 and $96 \mathrm{~h}$ after transfection, the cells were collected for extraction of total RNA and total proteins as described below.

Extraction of total RNA. PC12 cells were washed twice (3 min each) with phosphate-buffered saline (PBS) to extract the total RNA according to the manufacturer's instructions. RNAiso Plus (9108; Takara, Otsu, Japan) was added to a 6-well plate $(500 \mu \mathrm{l} / \mathrm{well})$ and mixed, followed by being transferred to a new Eppendorf (EP) tube and incubated at $4^{\circ} \mathrm{C}$ for $5 \mathrm{~min}$ and then centrifuged at 12,000 rpm for $10 \mathrm{~min}$. The supernatant was transferred to a new EP tube; $100 \mu 1$ of chloroform was added followed by vortexing for $15 \mathrm{sec}$, incubation at RT for $3 \mathrm{~min}$ and centrifugation at $12,000 \mathrm{rpm}$ for $15 \mathrm{~min}$. The upper water phase was transferred to a new EP tube, and $250 \mu 1$ of isopropanol was added and mixed. Then, the tube was placed in a $-20^{\circ} \mathrm{C}$ refrigerator for $1-2 \mathrm{~h}$ and centrifuged at $12,000 \mathrm{rpm}$ for $20 \mathrm{~min}$ at $4^{\circ} \mathrm{C}$. The supernatant was discarded, and $1 \mathrm{ml}$ of $75 \%$ ethanol was added, followed by centrifugation at $12,000 \mathrm{rpm}$ for $5 \mathrm{~min}$ at $4^{\circ} \mathrm{C}$, and this step was repeated once. The EP tube was incubated at RT for 5-10 min until the residual liquid had completely volatilized, and the pellet was dissolved with $20 \mu \mathrm{l}$ DEPC $\operatorname{ddH}_{2} \mathrm{O}$. The purity and the concentration of RNA were measured using ultraviolet spectroscopy.

Reverse transcription-quantitative polymerase chain reaction $(R T-q P C R)$ assay. The above-extracted total RNA was used as a template in a reverse transcription reaction using a ReverTra Ace qPCR RT kit (FSQ-101; Toyobo, Osaka, Japan), according to the manufacturer's instructions. The reaction mixture, including $10 \mu \mathrm{l}$ of $2 \mathrm{X}$ loading buffer, $1.2 \mu \mathrm{l}$ of oligo(dT), $2 \mu \mathrm{l}$ of RNA, $0.2 \mu \mathrm{l}$ of MMLV, and $6.6 \mu \mathrm{l}$ of DEPC $\mathrm{dd}_{2} \mathrm{O}$, was prepared and reacted at $65^{\circ} \mathrm{C}$ for $30 \mathrm{~min}$, then at $42^{\circ} \mathrm{C}$ for $30 \mathrm{~min}$, and then at $85^{\circ} \mathrm{C}$ for $10 \mathrm{~min}$. Subsequently, a total of $100 \mathrm{ng}$ of cDNA was used as the template in a RT-qPCR reaction using the $\mathrm{SYBR}^{\circledR}$ Premix Ex Taq ${ }^{\mathrm{TM}}$ kit (DRR420A; Takara), according to the manufacturer's instructions. The reaction mixture, including $10 \mu \mathrm{l}$ of $2 \mathrm{X}$ master mix, $0.1 \mu \mathrm{l}$ of forward primer, $0.1 \mu \mathrm{l}$ of reverse primer, $2 \mu \mathrm{l}$ of cDNA, $0.4 \mu \mathrm{l}$ of Taq DNA polymerase, and $7.4 \mu \mathrm{l}$ of $\mathrm{ddH}_{2} \mathrm{O}$, was prepared and used to performed RT-qPCR according to the following program: one cycle of $95^{\circ} \mathrm{C}$ for $3 \mathrm{~min} ; 40$ cycles of $95^{\circ} \mathrm{C}$ for $12 \mathrm{sec}, 62^{\circ} \mathrm{C}$ for $30 \mathrm{sec}$, and $72^{\circ} \mathrm{C}$ for $30 \mathrm{sec}$, using primers as 
follows: Nova1, pU, 5'-GGTCTCAGCCAAGCAGCAGCAA-3' and pD, 5'-TTGCAGCAGTAGCAGCAGCCAG-3'; glyceraldehyde 3-phosphate dehydrogenase (GAPDH), pU, 5'-TGGAT CTGACATGCCGCCTGGA-3' and pD, 5'-AGGTC CACCA CCCTGTTGCTGT-3'. The results were analyzed using SDS 1.4 software (Applied Biosystems, Foster City, CA, USA) based on the $2^{-\Delta \Delta \mathrm{Ct}}$ method, and histogram analysis was performed using Origin 9.5 software (http://www.originlab.com/).

Extraction of total protein. PC12 cells were washed with PBS twice ( 3 min each) to extract the total proteins according to the manufacturer's instructions [RIPA lysis buffer (P0013C); Beyotime, China]. Then, $50 \mu \mathrm{l}$ cell lysis buffer [50 mmol/1 Tris-Cl (pH 6.8), $2 \%$ SDS, $10 \%$ glycerol, 10 mM PMSF] was added, followed by incubation for $30 \mathrm{~min}$ on ice.Cells were collected using a cell scraper, and then transferred to an EP tube and centrifuged at $12,000 \mathrm{rpm}$ for $15 \mathrm{~min}$ at $4^{\circ} \mathrm{C}$. The supernatant was collected, and the protein concentration was measured using BCA protein assay reagent (Thermo Fisher Scientific Inc., Waltham, MA, USA).

Western blot assay. Samples of equal mass (35 $\mu \mathrm{g})$ were fractionated by electrophoresis through $12 \%$ polyacrylamide gels and transferred to polyvinylidene difluoride (PVDF) membranes (GE Healthcare, Piscataway, NJ, USA) according to the manufacturer's instructions. The membranes were probed with rabbit-derived anti-Nova1 polyclonal antibody (HPA004155; 1:500 in TBST; Sigma, St. Louis, MO, USA) and mouse-derived anti-Bax (BA0315)/Bcl-2 (BA0412)/ caspase-3 (BM3957)/GAPDH (BM1985) monoclonal antibody (1:500 in TBST) for $1.5 \mathrm{~h}$ at room temperature, followed by an HRP-conjugated goat anti-rabbit (BA1054) or anti-mouse (BA1050) secondary antibody (1:5,000 in TBST) (both from Wuhan Boster Biological Engineering Co., Ltd., Wuhan, China). Incubation was then carried out at RT for $1 \mathrm{~h}$. After that, the chemiluminescent substrate luminal reagent (GE) and exposure to X-ray film were used to examine the immunolabeled bands. The optical densities of the bands were scanned and quantified using ImageJ software version 1.46 (http://rsb. info.nih.gov/ij/).

Cell immunocytochemistry assay. PC12 cells were plated on polylysine-coated converslips in 6-well plates at an inoculation density of $2 \times 10^{5} / \mathrm{ml}$ and were cultured in a $\mathrm{CO}_{2}$-incubator with $5 \% \mathrm{CO}_{2}$ at $37^{\circ} \mathrm{C}$ for $15-30 \mathrm{~min}$, and then $1 \mathrm{ml}$ of DMEM was added and cells were cultured overnight. The following day, the plates were placed on ice, and the medium was discarded. The cells were washed 3 times (5 min each) with PBS. Cells were fixed with $4 \%$ paraformaldehyde for $30 \mathrm{~min}$ and then washed once with $\mathrm{ddH}_{2} \mathrm{O}(5 \mathrm{~min})$ and once with PBS (5 min). $\mathrm{Next}, 3 \% \mathrm{H}_{2} \mathrm{O}_{2}$ was added, incubation at $\mathrm{RT}$ for $30 \mathrm{~min}$, and the cells were washed 3 times with PBS. Then, $0.3 \%$ Triton X-100 was applied, followed by incubation at RT for $30 \mathrm{~min}$. Three washes (5 min each) with PBS and incubation with 5\% BSA for 20 min at RT were carried out. The slides were then placed in a cassette, incubated overnight with rabbit-derived anti-Noval polyclonal antibody at $4^{\circ} \mathrm{C}$, and washed 3 times (5 min each) with PBS. Subsequently, the slides were treated with biotinylated goat anti-rabbit IgG, and incubated at $37^{\circ} \mathrm{C}$ for $20 \mathrm{~min}$ followed by 3 washes with PBS. SABC reagent was applied for $20 \mathrm{~min}$ of incubation at $37^{\circ} \mathrm{C}$, followed by 3 washes $(5 \mathrm{~min}$ each) with PBS and development of DAB. The slides were dehydrated, cleared and mounted, and images were captured by microscopy. The average optical density was calculated using ImageJ software version 1.46 (http://rsb.info.nih.gov/ij/), and histogram analysis was performed using Origin 9.5 software (http://www.originlab.com/).

Establishment of a hypoxia model. PC12 cells were diluted, inoculated into 96 -well plates at $5 \times 10^{4} / \mathrm{ml}$, and cultured in a $\mathrm{CO}_{2}$-incubator with $5 \% \mathrm{CO}_{2}$ at $37^{\circ} \mathrm{C}$ for $24 \mathrm{~h}$. Then, the plates were placed in a hypoxic chamber, and a gas mixture of $95 \% \mathrm{~N}_{2}$ and $5 \% \mathrm{CO}_{2}$ was pumped in for 1-2 min. The air outlet was closed, and then a gas mixture of $95 \% \mathrm{~N}_{2}$ and $5 \% \mathrm{CO}_{2}$ was pumped in for $4 \mathrm{~min}$. Then, the air inlet was closed, and cells were incubated in a $\mathrm{CO}_{2}$ incubator with $5 \% \mathrm{CO}_{2}$ at $37^{\circ} \mathrm{C}$ for different durations of hypoxia, $0,2,4,6,8,12,24,48$ and $72 \mathrm{~h}$. Cells were collected for cell proliferation assays using methyl thiazolyl tetrazolium (MTT) and apoptosis assays using flow cytometry as follows. In addition, images of cells at 0 and $48 \mathrm{~h}$ of hypoxia were captured using an inverted microscope.

To examine the effect hypoxia on the expression of Nova1, PC12 cells transfected with pCMV-Myc or pCMV-Myc-Noval were subjected to $48 \mathrm{~h}$ of hypoxia. Then the mRNA expression of Noval was examined by RT-qPCR, and the protein expression of Nova1 was examined by western blot analysis, and the distribution of Nova1 in PC12 cells was examined using immunocytochemistry. In addition, the apoptosis rate was examined by flow cytometry $(E x=488 \mathrm{~nm}, E m=530 \mathrm{~nm})$. The mRNA expression levels of Bax, Bcl-2 and caspase-3 were examined by RT-qPCR and WB using the following primers: Bax, pU, 5'-CCAAGAAGCTGAGCGAGTGTC-3' and pD, 5'-TGAGGACTCCAGCCACAAAGA-3'; Bcl-2, pU, 5'-TGAA CCGGCATCTGCACAC-3' and pD, 5'-CGTCTTCAGAGAC AGCCAGGAG-3'; caspase-3, pU, 5'-GTGGAACTGACGAT GATATGGC-3' and pD, 5'-CGCAAAGTGACTGGATGA ACC-3'; GAPDH, pU, 5'-TGGATCTGACATGCCGCCT GGA-3' and pD, 5'-AGGTCCACCACCCTGTTGCTGT-3'.

Methyl thiazolyl tetrazolium (MTT) assay. After hypoxia as described above, $20 \mu 1$ of MTT (final concentration, $5 \mathrm{mg} / \mathrm{ml}$ ) was added to the cells, followed by incubation at $37^{\circ} \mathrm{C}$ for $4 \mathrm{~h}$. The supernatant was then discarded; cells were treated with $150 \mu \mathrm{l}$ of dimethyl sulfoxide (DMSO) to shock them for $5 \mathrm{~min}$, and the optical density (OD) at $490 \mathrm{~nm}$ was recorded using a microplate reader, with cell-free conditions as a control. The cellular survival rate was calculated based on the following formula: Cellular survival rate $=\left(\mathrm{OD}_{490}\right.$ of hypoxia group $/ \mathrm{OD}_{490}$ of control group) $\mathrm{x} 100 \%$.

Flow cytometric assay of apoptosis. Apoptosis was examined using the Annexin v-fitc apoptosis kit (BU-AP101; Biouniquer, San Diego, CA, USA) according to the manufacturer's instructions. After digestion with $0.25 \%$ trypsin, $\mathrm{PC} 12$ cells were washed twice with PBS and then centrifuged at 2,000 rpm for $5 \mathrm{~min}$. Next, the cells were resuspended in $500 \mu$ l Annexin V binding buffer, and $5 \mu 1$ of Annexin V-FITC was added to each sample, followed by the addition of $5 \mu \mathrm{l}$ PI and reaction at RT for $10 \mathrm{~min}$ in the dark. Subsequently, the apoptosis rate was examined using flow cytometry $(E x=488 \mathrm{~nm}, E m=530 \mathrm{~nm})$ 

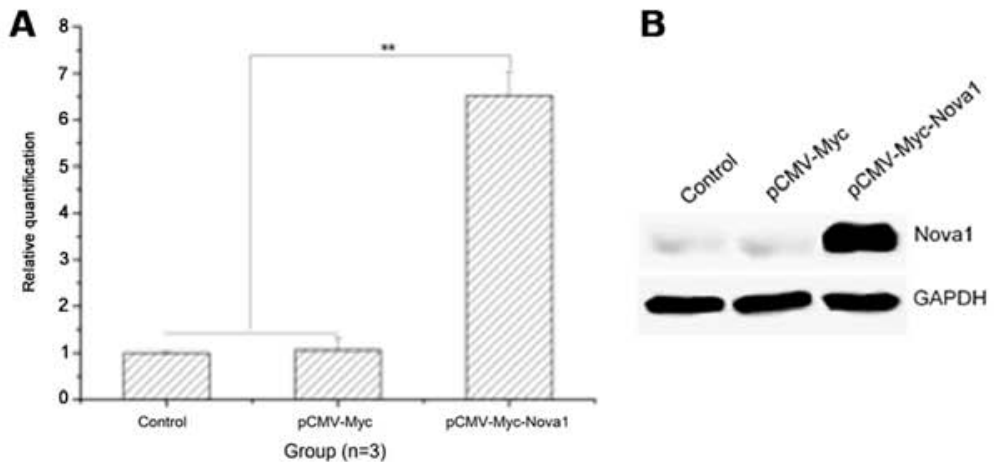

C

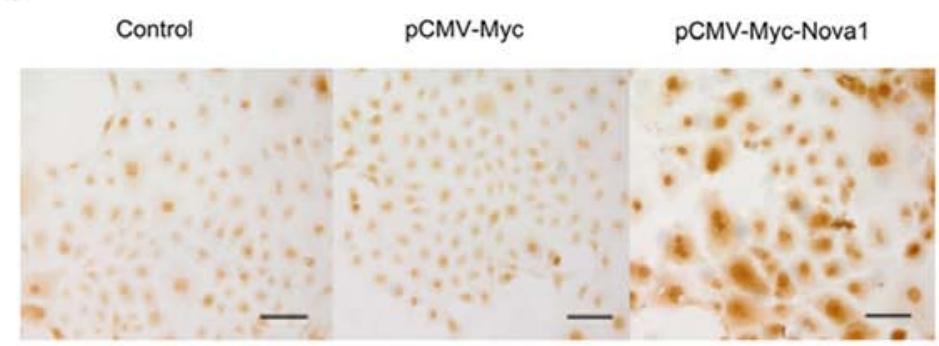

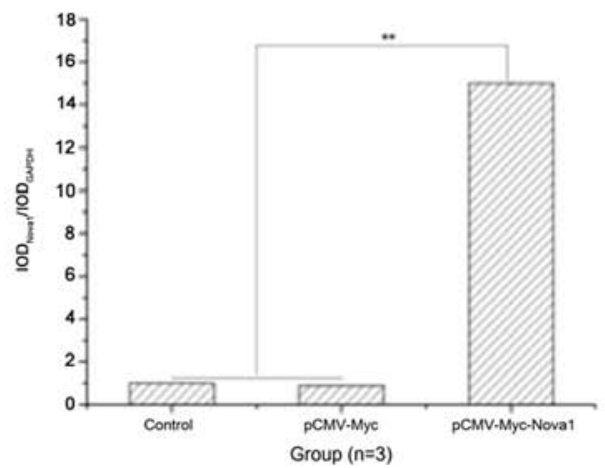

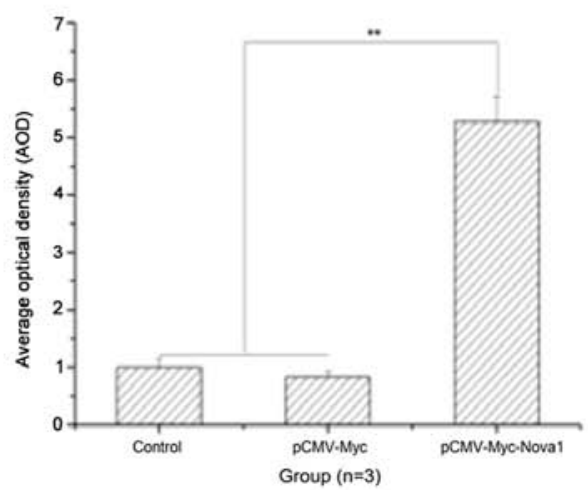

Figure 1. The mRNA and protein expression levels of neuro-oncological ventral antigen 1 (Nova1) in PC12 cells transfected with pCMV-Myc-Noval as detected by RT-qPCR, western blotting and cell immunocytochemistry. (A) The mRNA expression level of Nova1 as detected by RT-qPCR. (B) The protein expression level of Noval as detected by western blotting. (C) The protein expression and distribution of Noval as detected by cell immunocytochemistry. The images indicate that at $48 \mathrm{~h}$ after transfection, the mRNA and protein expression levels of Noval were significantly increased to a plateau, and widely distributed in the cytoplasm and nuclei $\left(^{* *} \mathrm{p}<0.01\right)$. Scale bar, $100 \mu \mathrm{m}$.

and analyzed using Origin 9.5 software (http://www.originlab. $\operatorname{com} /)$.

Statistical analysis. All data are expressed as the mean \pm SD. Statistical analysis was performed using SPSS software (version 21.0) (SPSS, Inc., Chicago, IL, USA) (http://spss. en.softonic.com/). In the Student's t-test, $\mathrm{p}<0.05$ and $\mathrm{p}<0.01$ indicate significant and highly significant differences, respectively.

\section{Results}

mRNA and protein expression levels of Noval are significantly increased in PC12 cells after transfection with pCMV-Myc-Noval, and Noval is widely distributed in the cytoplasm and nucleus. To identify the time of optimal expression of Nova1 in PC12 cells, Nova1 mRNA and protein expression was examined by RT-qPCR, western blot analysis and cell immunocytochemistry at 24, 48, 72 and $96 \mathrm{~h}$ after transfection, and the optimal expression time was $48 \mathrm{~h}$ after transfection (data not shown). At $48 \mathrm{~h}$ after transfection with pCMV-Myc-Noval, the mRNA and protein expression levels of Noval were significantly increased compared to those in the control and pCMV-Myc groups (p<0.01) (Fig. 1A and B), and Noval protein was also increased in the cytoplasm and nucleus (Fig. 1C).

Prolonged hypoxia significantly decreases the cell survival rate and increases the apoptosis rate. With prolonged duration of hypoxia, the survival rate of PC12 cells was significantly decreased ( $\mathrm{p}<0.01)$ (Fig. 2A). After $48 \mathrm{~h}$ of hypoxia, the cells showed shrinkage, the intercellular space was wider, and some cells had detached, floating in the medium (Fig. 2B). Additionally, the flow cytometry results showed that the survival rate of PC12 cells was significantly decreased, and the apoptosis rate of PC12 cells was constantly increased with prolonged hypoxia, peaking at $48 \mathrm{~h}$ of hypoxia $(\mathrm{p}<0.05$, p<0.01) (Fig. 3).

mRNA and protein expression levels of Noval are significantly increased in PC12 cells following transfection with $p C M V$ Myc-Noval after 48 hof hypoxia and the level of Noval is higher than the control groups. As shown in the RT-qPCR results, after $48 \mathrm{~h}$ of hypoxia, the mRNA expression of Noval was significantly increased in the PC12 cells following transfection with pCMV-Myc-Noval in contrast to the control and pCMV-Myc groups $(\mathrm{p}<0.01)$ (Fig. 4A). Similarly, as shown by the western blot analysis and cell immunocytochemistry results, the protein expression of Nova1 was also significantly increased in the PC12 cells transfected with pCMV-Myc-Noval in contrast to the control and pCMV-Myc groups, and the level of Noval was much higher than that in the control and pCMV-Myc groups $(\mathrm{p}<0.01)$ (Fig. 4B and C).

The apoptosis rate after 48 h of hypoxia is significantly decreased in PC12 cells following transfection with $p C M V-M y c-N o v a 1$. As shown by the flow cytometry results, after $48 \mathrm{~h}$ of hypoxia, the apoptosis rate of $\mathrm{PC} 12$ 
A

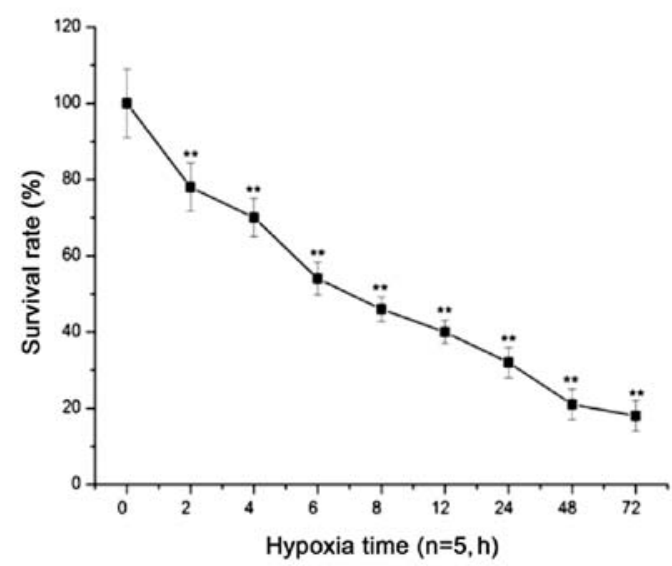

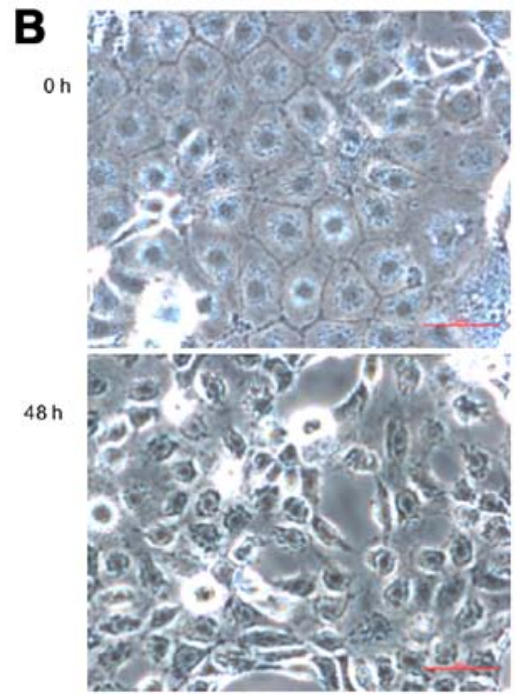

Figure 2. The survival rate and cell morphological structure of the PC12 cells during hypoxia as detected by methyl thiazolyl tetrazolium (MTT) assay and microscopy, respectively. (A) The survival rate of PC12 cells by MTT assay ( $\left.{ }^{* *} \mathrm{p}<0.01\right)$. (B) Cell morphological structure of the PC12 cells by microscopy. The images indicate that the survival rate was gradually decreased with prolonged hypoxia. Cells showed shrinkage, the intercellular space was wider, and some cells had detached, floating in the medium at $48 \mathrm{~h}$ of hypoxia. Scale bar, $100 \mu \mathrm{m}$.

A
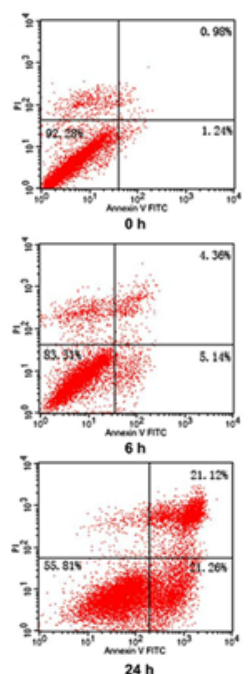
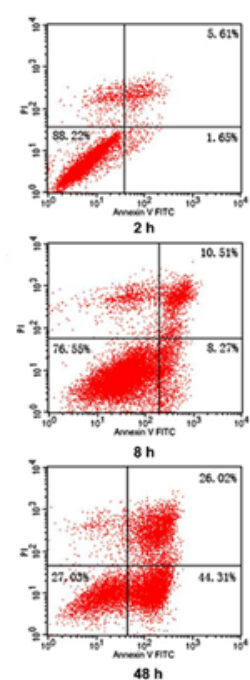
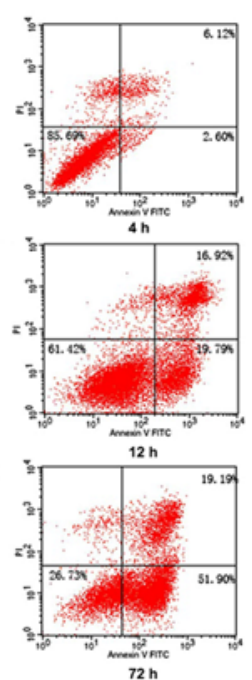

B

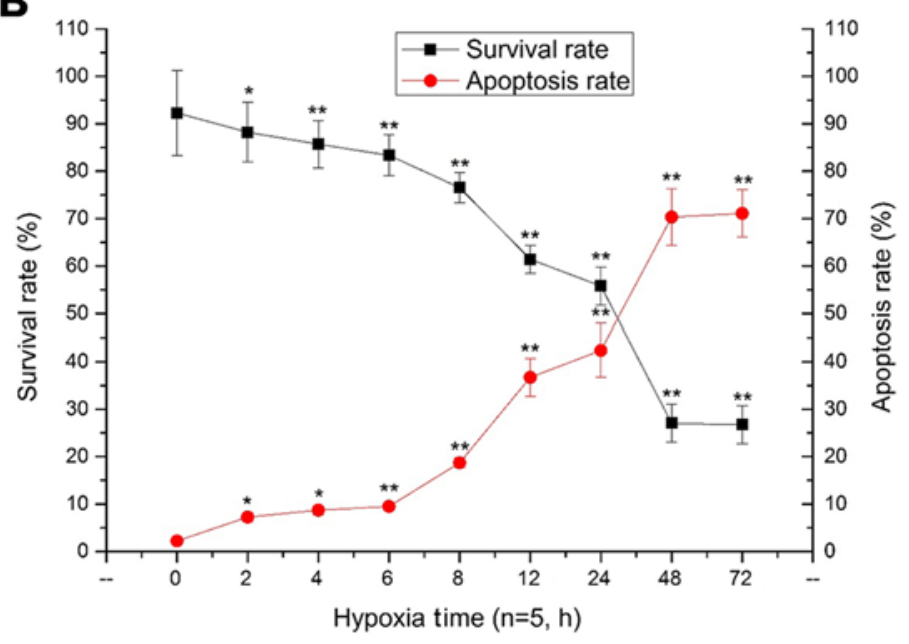

Figure 3. Apoptosis and survival rates of the PC12 cells during hypoxia as determined by flow cytometry and linear graphing. (A) The apoptosis rate by flow cytometry. (B) The survival rate by linear graphing. The images indicate that the apoptosis rate was constantly increased and the survival rate was decreased with prolonged hypoxia $\left({ }^{*} \mathrm{p}<0.05 ;{ }^{* *} \mathrm{p}<0.01\right)$.

cells was significantly decreased by transfection with pCMV-Myc-Noval compared with the control and pCMV-Myc groups ( $\mathrm{p}<0.01$ ) (Fig. 5). Significantly, after $48 \mathrm{~h}$ of hypoxia, the mRNA and protein expression levels of Bax and caspase-3 were significantly increased in the pCMVMyc group in comparison to the control and significantly decreased in the pCMV-Myc-Noval group in comparison to the pCMV-Myc group ( $\mathrm{p}<0.01)$ (Fig. 6). Furthermore, the mRNA and protein expression levels of Bcl-2 were significantly decreased in the pCMV-Myc group in comparison to the control, and significantly increased in the pCMVMyc-Noval group in comparison to the pCMV-Myc group $(\mathrm{p}<0.01)$ (Fig. 6). These results indicate that Noval induces resistance to hypoxia-induced apoptosis in PC12 cells via the $\mathrm{Bax} / \mathrm{Bcl}-2 /$ caspase-3 pathway.

\section{Discussion}

The present study demonstrated that Noval was highly expressed in PC12 cells at $48 \mathrm{~h}$ after transfection and was widely distributed in the cytoplasm and nucleus. After continuous hypoxia of untransfected PC12 cells, the cell survival rate was gradually decreased, and the apoptosis rate was gradually increased compared to the control. Upon $48 \mathrm{~h}$ of hypoxia in PC12 cells overexpressing Noval, the cell apoptosis rate was significantly decreased and the survival rate was significantly increased. The mRNA and protein expression levels of Bax and caspase- 3 were also significantly decreased, and the mRNA and protein expression levels of Bcl-2 were significantly increased, indicating that Noval could induce resistance to hypoxia-induced apoptosis in $\mathrm{PC} 12$ cells via the Bax/Bcl-2/caspase-3 pathway. 

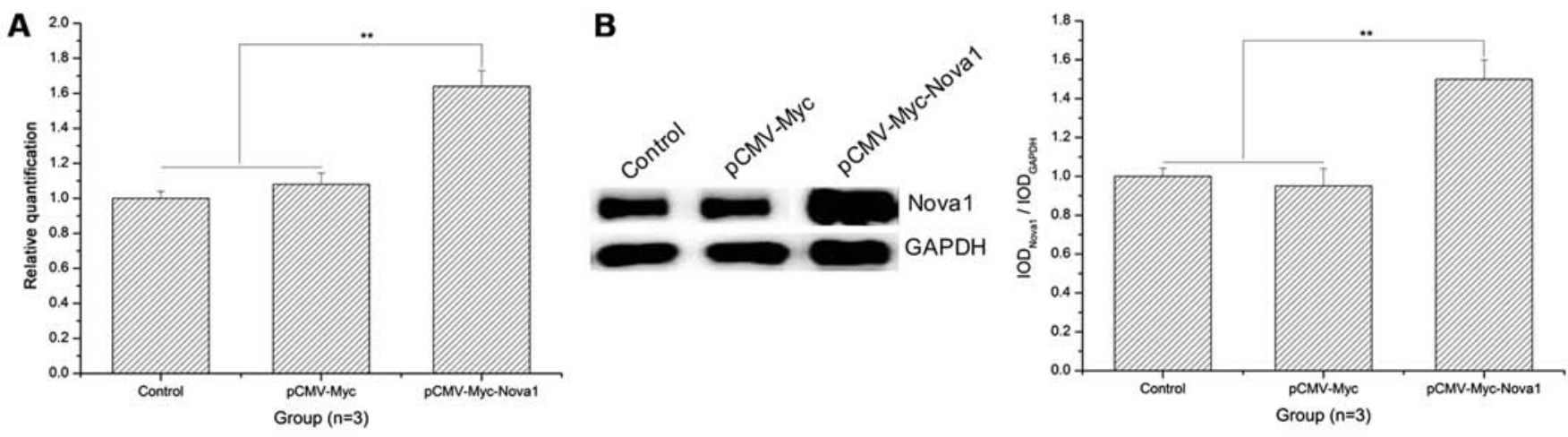

C

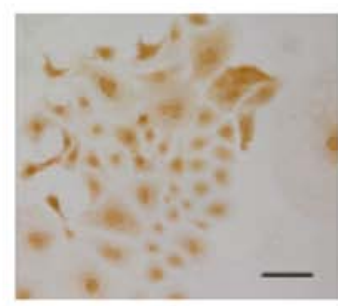

pCMV-Myc

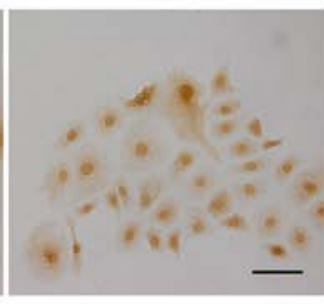

pCMV-Myc-Nova1

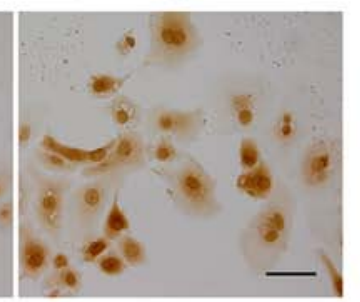

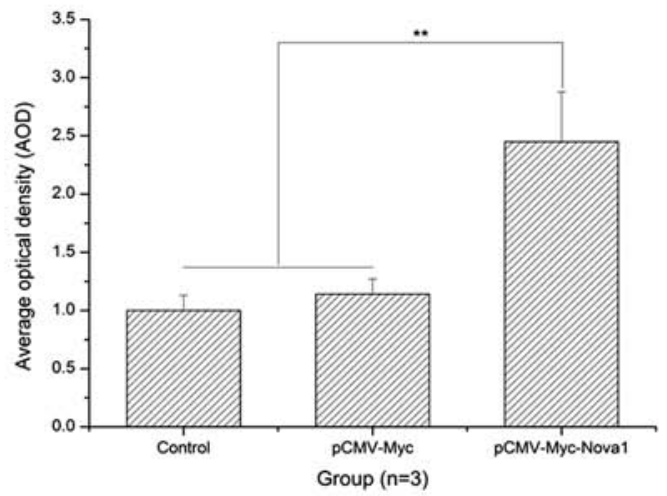

Figure 4. mRNA and protein expression levels of neuro-oncological ventral antigen 1 (Nova1) in PC12 cells transfected with pCMV-Myc-Noval as determined by RT-qPCR, western blotting and cell immunocytochemistry at $48 \mathrm{~h}$ hypoxia. (A) The mRNA expression level of Noval by RT-qPCR at $48 \mathrm{~h}$ hypoxia. (B) The protein expression level of Noval by western blotting at $48 \mathrm{~h}$ hypoxia. (C) The protein expression level and distribution of Noval assay by cell immunocytochemistry at $48 \mathrm{~h}$ hypoxia. The images indicate that at $48 \mathrm{~h}$ hypoxia, the mRNA and protein expression levels were significantly increased $\left({ }^{* *}\right.$ p $\left.<0.01\right)$. Scale bar, $100 \mu \mathrm{m}$.

A

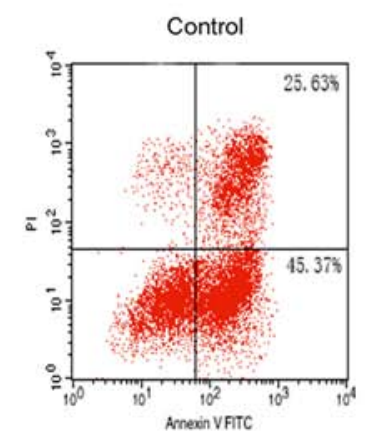

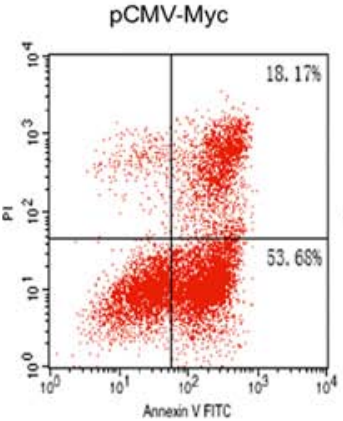

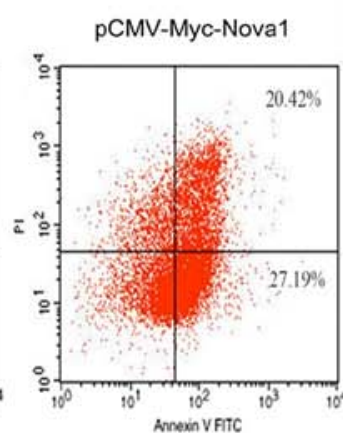

B

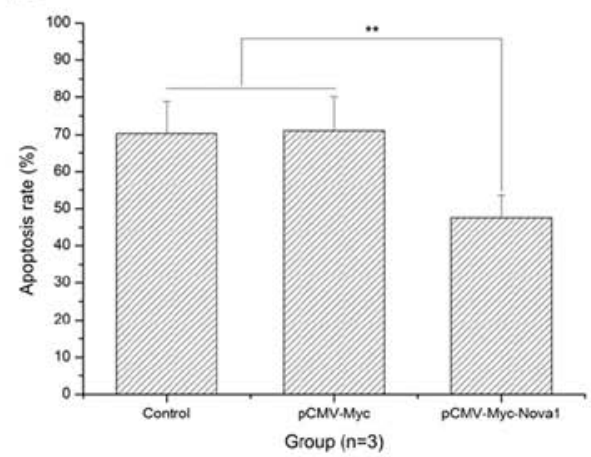

Figure 5. The apoptosis rate of the PC12 cells transfected with pCMV-Myc-Noval as detected by flow cytometry. (A) The apoptosis rate by flow cytometry. (B) The apoptosis rate as shown by a histogram. The images indicate that the apoptosis rate was constantly increased after $48 \mathrm{~h}$ hypoxia and significantly decreased after transfection of pCMV-Myc-Noval $\left({ }^{* *} \mathrm{p}<0.01\right)$.

Recently, alternative splicing has been regarded as a major mechanism for increasing proteomic complexity and protein function diversity, and alternative splicing has been shown to play a significant role in the regulation of gene expression and protein function diversity (31-33). Alternative splicing is much more common in the brain than in other organs $(34,35)$, and it is also often involved in ischemia-reperfusion injury to the brain as described in our previous study (29). However, the mechanism by which Noval participates in ischemia-reperfusion injury of the brain remains unknown. To address this question, the eukaryotic expression vector pCMV-Myc was chosen for the expression of Nova1 cDNA. pCMV-Myc contains a strong promoter from cytomegalovirus (CMV) that can transcribe exogenous genes early and shows strong expression efficiency. Regarding the regulation of the CMV promoter, at $48 \mathrm{~h}$ after transfection with pCMV-Myc-Noval, the mRNA and protein expression levels of Noval were significantly increased, and Noval was also increased in the cytoplasm and nucleus.

The brain accounts for only $2 \%$ of the body weight in humans but uses $\sim 15 \%$ of the cardiac output and $\sim 20 \%$ of oxygen consumption of the whole body. In addition, hypoxia produces 
A

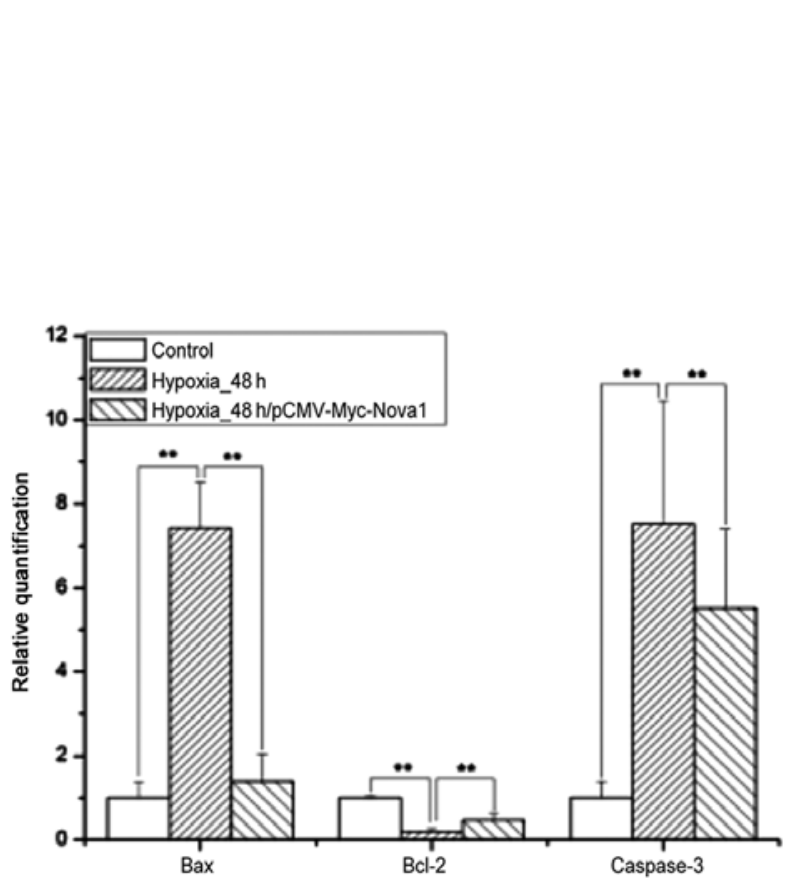

B
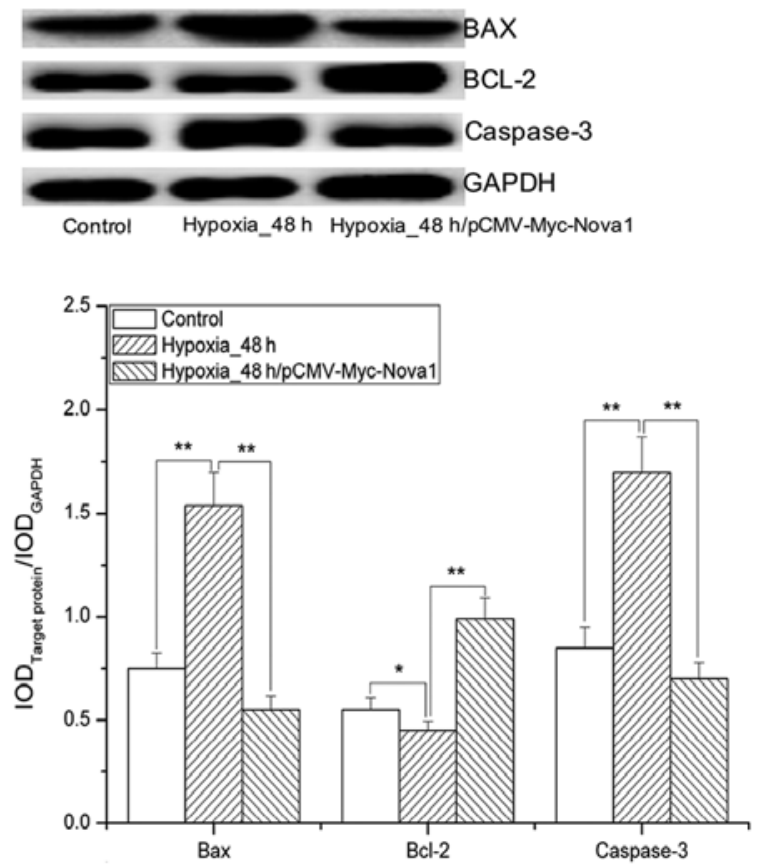

Figure 6. mRNA and protein expression level sof Bcl-2 associated gene X (Bax), B cell lymphoma gene-2 (Bcl-2) and caspase-3 as determined by RT-qPCR and western blotting in the PC12 cells after 48 h hypoxia. (A) The mRNA expression levels of Bax, Bcl-2 and caspase-3 by RT-qPCR. (B) The protein expression levels of Bax, Bcl-2 and caspase- 3 by western blotting. The images indicate that after 48 hypoxia, the mRNA and protein expression levels of Bax and caspase-3 were significantly increased, and also obviously decreased after transfection of pCMV-Myc-Noval, and that of Bcl-2 was significantly decreased, and also obviously increased after transfection of pCMV-Myc-Noval $\left({ }^{*} \mathrm{p}<0.05 ;{ }^{* *} \mathrm{p}<0.01\right)$.

even greater damage in the brain than in other tissues, and it severely affects the normal physiological functions of various organs $(36,37)$. In the study of hypoxic injury of the brain and its associated diseases, stabilized neuronal hypoxia models have often been established in vitro, including the $\mathrm{PC} 12$ hypoxia model using a hypoxic chamber. PC12 cells are derived from rat pheochromocytoma cells, separated from a rat pheochromocytoma by Greene and Tischler in 1976. They show many characteristics of nerve cells (38). PC12 cells are therefore often used as an ideal in vitro cell model for nervous system diseases (39-41). Here, PC12 cells were subjected to oxygen deprivation using a hypoxic chamber to mimic hypoxia, and the cell survival and apoptosis rates were examined by MTT assay and flow cytometry, respectively. After continuous hypoxia, the cell survival rate was gradually declined, and the apoptosis rate was steadily increased by hypoxia in a time-dependent manner. These results indicated that the PC12 cell hypoxia model was correctly established. After hypoxia, Noval protein expression was significantly increased, indicating that hypoxia could induce the strong splicing activity of Noval and that cells may activate a compensatory reaction. In addition, Noval protein was widely expressed in the cytoplasm and nuclei, especially in the nuclei indicating that Noval may be involved in the processing of RNAs in neurons.

Several studies have documented that apoptosis is induced both in the delayed neuronal cell death after transient brain hypoxia and by acute focal brain ischemia (42-46). Normally, the anti-apoptosis and pro-apoptosis proteins are metastable in organisms, and it requires several pro-apoptosis elements to induce apoptosis. Bcl-2 is an anti-apoptosis protein and can regulate apoptosis by binding pro-apoptosis proteins, such as Bax, Bad or $\mathrm{Bcl}-\mathrm{xl}$; therefore the ratio of $\mathrm{Bcl}-2$ to $\mathrm{Bax}$ has been regarded as a critical factor in cell survival or death $(47,48)$. In this study, after $48 \mathrm{~h}$ of hypoxia, the mRNA expression level of Bcl-2 was significantly decreased, that of Bax was obviously increased, and the ratio of Bcl-2 to Bax was decreased. This indicated that the pro-apoptotic effect of Bax was greater than the anti-apoptotic effect of Bcl-2, finally resulting in apoptosis. After transfection of pCMV-Myc-Noval, the mRNA and protein expression levels of Bcl-2 were increased, levels of Bax were significantly decreased, and the ratio of Bcl-2 to Bax was increased, thus indicating that Noval could protect against hypoxia-induced neuronal injury by regulating the ratio of Bcl-2 to Bax. Additionally, in comparison to the control, the mRNA and protein expression levels of caspase- 3 were significantly increased after $48 \mathrm{~h}$ of hypoxia and significantly decreased upon transfection of pCMV-Myc-Noval, indicating that Nova1 may be involved in regulating hypoxiainduced apoptosis via the caspase-3 pathway.

In conclusion, the eukaryotic expression vector pCMV-Myc-Noval was constructed and transfected into the PC12 cells during hypoxia. Our study demonstrated that Noval is associated with resistance to the hypoxia-induced apoptosis of $\mathrm{PC} 12$ cells via the $\mathrm{Bax} / \mathrm{Bcl}-2 /$ caspase- 3 pathway. This discovery provides evidence of Noval to explore the novel mechanism during hypoxia.

\section{Acknowledgements}

We would like to thank Gorospe Myraim of the National Institute on Aging (NIA) (National Institutes of Health, Bethesda, MD, USA) for the antibody and plasmid pCMV-myc. 
This study was supported by the National Science Foundation of China (nos. 81671056, 81372237 and 81100862) and the Yangzhou University and CSC (no. 2015CXJ070).

\section{References}

1. Belo AI, van Vliet SJ, Maus A, Laan LC, Nauta TD, Koolwijk P, Tefsen B and van Die I: Hypoxia inducible factor $1 \alpha$ down regulates cell surface expression of $\alpha 1,2$-fucosylated glycans in human pancreatic adenocarcinoma cells. FEBS Lett 589: 2359-2366, 2015.

2. Chen HC, Lee JT, Shih CP, Chao TT, Sytwu HK, Li SL, Fang MC, Chen HK, Lin YC, Kuo CY, et al: Hypoxia induces a metabolic shift and enhances the stemness and expansion of cochlear spiral ganglion stem/progenitor cells. Biomed Res Int 2015: 359537, 2015.

3. de Oliveira JT, Ribeiro C, Barros R, Gomes C, de Matos AJ, Reis CA, Rutteman GR and Gärtner F: Hypoxia up-regulates galectin-3 in mammary tumor progression and metastasis. PLoS One 10: e0134458, 2015.

4. Bonestroo HJ, Nijboer $\mathrm{CH}$, van Velthoven $\mathrm{CT}$, van Bel F and Heijnen CJ: The neonatal brain is not protected by osteopontin peptide treatment after hypoxia-ischemia. Dev Neurosci 37: $142-152,2015$

5. Cui C, Zhou T, Li J, Wang H, Li X, Xiong J, Xu P and Xue M: Proteomic analysis of the mouse brain after repetitive exposure to hypoxia. Chem Biol Interact 236: 57-66, 2015.

6. Kimura W, Xiao F, Canseco DC, Muralidhar S, Thet S, Zhang HM, Abderrahman Y, Chen R, Garcia JA, Shelton JM, et al: Hypoxia fate mapping identifies cycling cardiomyocytes in the adult heart. Nature 523: 226-230, 2015.

7. Siebenmann C, Rasmussen P, Sørensen H, Bonne TC, Zaar M Aachmann-Andersen NJ, Nordsborg NB, Secher NH and Lundby $C$ : Hypoxia increases exercise heart rate despite combined inhibition of $\beta$-adrenergic and muscarinic receptors Am J Physiol Heart Circ Physiol 308: H1540-H1546, 2015.

8. Calbet JA, Boushel R, Rådegran G, Søndergaard H, Wagner PD and Saltin B: Determinants of maximal oxygen uptake in severe acute hypoxia. Am J Physiol Regul Integr Comp Physiol 284: R291-R303, 2003.

9. Gonchar O and Mankovskaya I: Effect of moderate hypoxia/ reoxygenation on mitochondrial adaptation to acute severe hypoxia. Acta Biol Hung 60: 185-194, 2009.

10. Sanotskaya NV, Matsievskii DD and Lebedeva MA: Effect of picrotoxin on organism's resistance to acute severe hypoxia. Bull Exp Biol Med 145: 177-180, 2008.

11. Beltran-Parrazal L, Acuna D, Ngan AM, Kim E, Ngan A, Kawakami K, Edmond J and Lopez IA: Neuroglobin, cytoglobin, and transcriptional profiling of hypoxia-related genes in the rat cerebellum after prenatal chronic very mild carbon monoxide exposure (25 ppm). Brain Res 1330: 61-71, 2010.

12. Dore-Duffy P, Wencel M, Katyshev V and Cleary K: Chronic mild hypoxia ameliorates chronic inflammatory activity in myelin oligodendrocyte glycoprotein (MOG) peptide induced experimental autoimmune encephalomyelitis (EAE). Adv Exp Med Biol 701: 165-173, 2011.

13. Lima-Ojeda JM, Vogt MA, Richter SH, Dormann C, Schneider M, Gass $\mathrm{P}$ and Inta D: Lack of protracted behavioral abnormalities following intermittent or continuous chronic mild hypoxia in perinatal C57BL/6 mice. Neurosci Lett 577: 77-82, 2014.

14. Hu Q, Wu C, Chen JY, Yan F, Li JR and Chen G: The relationship between hypoxia-inducible factor-1 $\alpha$ expression and apoptosis in early brain injury after subarachnoid hemorrhage. Zhejiang Da Xue Xue Bao Yi Xue Ban 43: 58-65, 2014 (In Chinese).

15. Xuan M, Okazaki M, Iwata N, Asano S, Kamiuchi S, Matsuzaki H, Sakamoto T, Miyano Y, Iizuka H and Hibino Y: Chronic treatment with a water-soluble extract from the culture medium of Ganoderma lucidum mycelia prevents apoptosis and necroptosis in hypoxia/ischemia-induced injury of type 2 diabetic mouse brain. Evid Based Complement Alternat Med 2015: 865986, 2015

16. Liu B, Zhang YH, Jiang Y, Li LL, Chen Q, He GQ, Tan XD and Li CQ: Gadd45b is a novel mediator of neuronal apoptosis in ischemic stroke. Int J Biol Sci 11: 353-360, 2015.

17. Lv H, Wang L, Shen J, Hao S, Ming A, Wang X, Su F and Zhang Z: Salvianolic acid B attenuates apoptosis and inflammation via SIRT1 activation in experimental stroke rats. Brain Res Bull 115: 30-36, 2015.
18. Fang L, Gao H, Zhang W, Zhang W and Wang Y: Resveratrol alleviates nerve injury after cerebral ischemia and reperfusion in mice by inhibiting inflammation and apoptosis. Int J Clin Exp Med 8: 3219-3226, 2015.

19. Zhao P, Zhou R, Zhu XY, Hao YJ, Li N, Wang J, Niu Y, Sun T, Li YX and Yu JQ: Matrine attenuates focal cerebral ischemic injury by improving antioxidant activity and inhibiting apoptosis in mice. Int J Mol Med 36: 633-644, 2015.

20. Daulatzai MA: Death by a thousand cuts in Alzheimer's disease: Hypoxia - the prodrome. Neurotox Res 24: 216-243, 2013.

21. Liu H, Qiu H, Yang J, Ni J and Le W: Chronic hypoxia facilitates Alzheimer's disease through demethylation of $\gamma$-secretase by downregulating DNA methyltransferase 3b. Alzheimers Dement 12: 130-143, 2016.

22. Schmid D, Fay F, Small DM, Jaworski J, Riley JS, Tegazzini D, Fenning C, Jones DS, Johnston PG, Longley DB, et al: Efficient drug delivery and induction of apoptosis in colorectal tumors using a death receptor 5-targeted nanomedicine. Mol Ther 22: 2083-2092, 2014

23. Walter RF, Werner R, Ting S, Vollbrecht C, Theegarten D, Christoph DC, Schmid KW, Wohlschlaeger J and Mairinger FD: Identification of deregulation of apoptosis and cell cycle in neuroendocrine tumors of the lung via NanoString nCounter expression analysis. Oncotarget 6: 24690-24698, 2015.

24. Darnell RB and Posner JB: Paraneoplastic syndromes involving the nervous system. N Engl J Med 349: 1543-1554, 2003.

25. Ratti A, Fallini C, Colombrita C, Pascale A, Laforenza U, Quattrone A and Silani V: Post-transcriptional regulation of neuro-oncological ventral antigen 1 by the neuronal RNA-binding proteins ELAV. J Biol Chem 283: 7531-7541, 2008.

26. Buckanovich RJ and Darnell RB: The neuronal RNA binding protein Nova-1 recognizes specific RNA targets in vitro and in vivo. Mol Cell Biol 17: 3194-3201, 1997.

27. Zhang YA, Zhu JM, Yin J, Tang WQ, Guo YM, Shen XZ and Liu TT: High expression of neuro-oncological ventral antigen 1 correlates with poor prognosis in hepatocellular carcinoma. PLoS One 9: e90955, 2014.

28. Dredge BK and Darnell RB: Nova regulates GABA(A) receptor gamma2 alternative splicing via a distal downstream UCAU-rich intronic splicing enhancer. Mol Cell Biol 23: 4687-4700, 2003.

29. Li H, Sun C, Wang Y, Gao Y, Liu Y, Gao Y, Li X and Zhang C: Dynamic expression pattern of neuro-oncological ventral antigen 1 (Nova1) in the rat brain after focal cerebral ischemia/ reperfusion insults. J Histochem Cytochem 61: 45-54, 2013.

30. Dredge BK, Stefani G, Engelhard CC and Darnell RB: Nova autoregulation reveals dual functions in neuronal splicing. EMBO J 24: 1608-1620, 2005.

31. Nishida A, Minegishi M, Takeuchi A, Awano H, Niba ET and Matsuo M: Neuronal SH-SY5Y cells use the C-dystrophin promoter coupled with exon 78 skipping and display multiple patterns of alternative splicing including two intronic insertion events. Hum Genet 134: 993-1001, 2015.

32. Stepankiw N, Raghavan M, Fogarty EA, Grimson A and Pleiss JA: Widespread alternative and aberrant splicing revealed by lariat sequencing. Nucleic Acids Res 43: 8488-8501, 2015.

33. Stephan-Otto Attolini C, Peña V and Rossell D: Designing alternative splicing RNA-seq studies. Beyond generic guidelines. Bioinformatics 31: 3631-3637, 2015.

34. Schreiner D, Nguyen TM, Russo G, Heber S, Patrignani A, Ahrné E and Scheiffele P: Targeted combinatorial alternative splicing generates brain region-specific repertoires of neurexins. Neuron 84: 386-398, 2014.

35. Trifonov S, Yamashita Y, Kase M, Maruyama M and Sugimoto T: Glutamic acid decarboxylase 1 alternative splicing isoforms: Characterization, expression and quantification in the mouse brain. BMC Neurosci 15: 114, 2014.

36. Cantagrel S, Krier C, Ducrocq S, Bodard S, Payen V, Laugier J, Guilloteau D and Chalon S: Hypoxic preconditioning reduces apoptosis in a rat model of immature brain hypoxia-ischaemia. Neurosci Lett 347: 106-110, 2003.

37. Williamson DJ, Ejaz S, Sitnikov S, Fryer TD, Sawiak SJ, Burke P Baron JC and Aigbirhio FI: A comparison of four PET tracers for brain hypoxia mapping in a rodent model of stroke. Nucl Med Biol 40: 338-344, 2013.

38. Greene LA and Tischler AS: Establishment of a noradrenergic clonal line of rat adrenal pheochromocytoma cells which respond to nerve growth factor. Proc Natl Acad Sci USA 73: 2424-2428, 1976.

39. Dichter MA, Tischler AS and Greene LA: Nerve growth factorinduced increase in electrical excitability and acetylcholine sensitivity of a rat pheochromocytoma cell line. Nature 268: 501-504, 1977. 
40. McGuire JC, Greene LA and Furano AV: NGF stimulates incorporation of fucose or glucosamine into an external glycoprotein in cultured rat PC12 pheochromocytoma cells. Cell 15: 357-365, 1978.

41. Rudy B, Kirschenbaum B and Greene LA: Nerve growth factor-induced increase in saxitoxin binding to rat PC12 pheochromocytoma cells. J Neurosci 2: 1405-1411, 1982.

42. Gutsaeva DR, Carraway MS, Suliman HB, Demchenko IT, Shitara H, Yonekawa $\mathrm{H}$ and Piantadosi CA: Transient hypoxia stimulates mitochondrial biogenesis in brain subcortex by a neuronal nitric oxide synthase-dependent mechanism. J Neurosci 28: 2015-2024, 2008.

43. Huang NC, Yongbi MN and Helpern JA: The influence of preischemic hyperglycemia on acute changes in brain water $\mathrm{ADCw}$ following focal ischemia in rats. Brain Res 788: 137-143, 1998.

44. Liu KF, Li F, Tatlisumak T, Garcia JH, Sotak CH, Fisher M and Fenstermacher JD: Regional variations in the apparent diffusion coefficient and the intracellular distribution of water in rat brain during acute focal ischemia. Stroke 32: 1897-1905, 2001.
45. Roehl AB, Zoremba N, Kipp M, Schiefer J, Goetzenich A, Bleilevens C, Kuehn-Velten N, Tolba R, Rossaint R and Hein M: The effects of levosimendan on brain metabolism during initial recovery from global transient ischaemia/hypoxia. BMC Neurol 12: 81, 2012.

46. Shi Q, Zhang P, Zhang J, Chen X, Lu H, Tian Y, Parker TL and Liu Y: Adenovirus-mediated brain-derived neurotrophic factor expression regulated by hypoxia response element protects brain from injury of transient middle cerebral artery occlusion in mice. Neurosci Lett 465: 220-225, 2009.

47. Carpio MA, Michaud M, Zhou W, Fisher JK, Walensky LD and Katz SG: BCL-2 family member BOK promotes apoptosis in response to endoplasmic reticulum stress. Proc Natl Acad Sci USA 112: 7201-7206, 2015.

48. Lee HJ, Lee EK, Seo YE, Shin YH, Kim HS, Chun YH, Yoon JS, Kim HH, Han MY, Kim CK, et al: Roles of Bcl-2 and caspase-9 and -3 in CD30-induced human eosinophil apoptosis. J Microbiol Immunol Infect 50: 145-152, 2017. 